\title{
STRUCTURAL ANALYSIS OF A STEEL COLUMN EXPOSED TO A LOCALIZED FIRE
}

Scientiffic paper / Znanstveni rad

\section{Tonko Faldić}

(Received: 13 October 2017; accepted: 14 November 2017)

University of Split, Faculty of Civil Engineering, Architecture and Geodesy, Master Student

Corresponding author: tonko.faldic@gmail.com

Helder David Craveiro

ISISE - University of Coimbra, Faculty of Science and Technology, Department of Civil Engineering, Invited Assistant Professor

\section{Aldina Santiago}

ISISE - University of Coimbra, Faculty of Science and Technology, Department of Civil Engineering, Assistant Professor

\section{Neno Torić}

University of Split, Faculty of Civil Engineering, Architecture and Geodesy, Assistant Professor

\begin{abstract}
This paper presents an investigation on the structural analysis of a steel column exposed to a localized fire. Because EN 1991-1-2 does not provide a simplified method to calculate heat transfer to vertical elements, a CFD (Computational Fluid Dynamics) model of a localized fire is developed, based on previously conducted experiments. Furthermore, a heat transfer analysis was performed based on the results of CFD modeling and for the ISO temperature-time curve. Finally, a nonlinear structural analysis of the steel column was conducted for the localized fire scenario, as well as for the ISO temperature-time curve. A comparison between the localized fire and ISO fire exposure points indicates that localized fires can cause earlier failure of a column, depending on the level of external load.
\end{abstract}

Keywords: fire modeling; localized fire; heat transfer; structural analysis; nonlinear analysis; steel

\section{ANALIZA NOSIVOSTI ČELIČNOG STUPA IZLOŽENOG LOKALIZIRANOM POŽARU}

Sažetak: U ovome radu prikazana je analiza nosivosti čeličnog stupa izloženog djelovanju lokaliziranog požara. Budući da EN 1991-1-2(2002) ne propisuje pojednostavljeni postupak proračuna provođenja topline za vertikalne elemente, izrađen je CFD model na temelju prethodno provedenih požarnih eksperimenata. Na temelju CFD modela izrađen je model provođenja topline za lokalizirani požar, kao i za standardnu požarnu krivulju. Naposlijetku, provedena je nelinearna statička analiza čeličnog stupa izloženog lokaliziranom požaru, kao i za ISO krivulju temperatura - vrijeme. Usporedba između lokaliziranog požara i modela standardnog požara pokazuje da lokalizirani požar, ovisno o veličini opterećenja, može dovesti do ranijeg otkazivanja stupa.

Ključne riječi: požarna analiza; lokalizirani požar; provođenje topline; analiza nosivosti; nelinearna analiza; čelik 


\section{INTRODUCTION}

This paper presents an application of a performance-based approach for investigating the behavior of a steel column exposed to a localized fire. EN1991-1-2, [1] provides a simple calculation approach for determining localized fires within compartments. However, there is no available simplified method that considers heat transfer to vertical elements. Therefore, a need to investigate the effect of localized fires on vertical structural elements, such as columns, is necessary. This paper is based on an analysis performed within the master thesis titled "Structural analysis of the steel column exposed to a localized fire" at the University of Split, [2].

A performance-based approach involves the assessment of three basic analysis components, namely, fire modeling, thermal analysis, and structural response.

Fire modeling was performed by conducting a CFD (Computational Fluid Dynamics) analysis of the development of fire temperatures based on experiments conducted within the SUSCOS (Sustainable Constructions under Natural Hazards and Catastrophic Events) master thesis by Gonçalo Ferraz, [3]. The experiments included investigating temperature evolution along a steel column exposed to a localized pool fire. The CFD analysis was performed using the CFD model FDS (Fire Dynamics Simulator), where the thermal action is defined by the combustion and complex pyrolysis model of a diesel pool fire. A realistic thermal action within the fire compartment was simulated. In the subsequent analysis, steel temperatures were obtained using $3 \mathrm{D}$ heat transfer calculation.

Thermal analysis was performed in order to resolve the 3D heat transfer phenomena by using the finite element software Abaqus/CAE. Heat transfer from flame consists of three basic components, namely, convection, radiation, and conduction. In order to resolve heat transfer and calculate steel temperatures, adiabatic surface temperatures, [4] obtained from a fire model, as well as the standard temperature-time fire curve proposed by EN1992-1-2, were used, [1].

Structural analysis presents the last part of the performance based approach. The purpose of the structural analysis was to investigate the behavior of a steel column exposed to a localized fire. A nonlinear analysis with geometric imperfections included was conducted using the same finite element software, Abaqus/CAE. The thermal load was based on temperatures calculated with the help of the thermal analysis and combined with several load levels of axial compressive force. Finally, a comparison is made for a column subjected to a thermal load calculated using the standard temperature-time curve.

\section{EXPERIMENTAL WORK}

The aforementioned thesis is a continuation of a SUSCOS thesis by Gonçalo Ferraz, [3]. Full-scale tests were performed in a large fire compartment, where a steel column was exposed to distinct localized fire scenarios. The internal dimensions of the compartment were $10 \mathrm{~m} \times 9.75 \mathrm{~m} \times 3 \mathrm{~m}$. During the fire experiments, an unloaded cold formed circular hollow steel column was subjected to fire. The diameter of the column was $245 \mathrm{~mm}$, and its thickness and height were $10 \mathrm{~mm}$ and $2.90 \mathrm{~m}$, respectively. The height of the column was slightly lower than that of the compartment to avoid additional stresses caused by thermal elongation, [5]. The column was hollow, and both ends of the column were sealed. Thermal action was applied through pool fires filled with liquid fuel and placed in distinct positions inside the fire compartment (Figure 1).

The temperatures were registered using wire thermocouples $60 \mathrm{~K}$-type thermocouples with two $0.5-\mathrm{mm}$ diameter wires were used to monitor steel and gas temperatures. In each section, four equally spaced thermocouples were welded to the column for monitoring the steel temperature $\left(\mathrm{TS}_{\mathrm{j}}\right.$, where $j$ is the section number and $i$ is the cross-section position number). In addition, gas temperatures were monitored using four thermocouples placed $5 \mathrm{~cm}$ away from the ones welded to the column $\left(\mathrm{TG}_{\mathrm{ji}}\right)$. Furthermore, at the same levels, temperature was measured along the vertical axis of fire plume $\left(\mathrm{TF}_{\mathrm{j}}\right)$. The layout of the thermocouples is presented in Figure 1.

Faldić, T, Craveiro, H, Santiago, A, Torić, N 


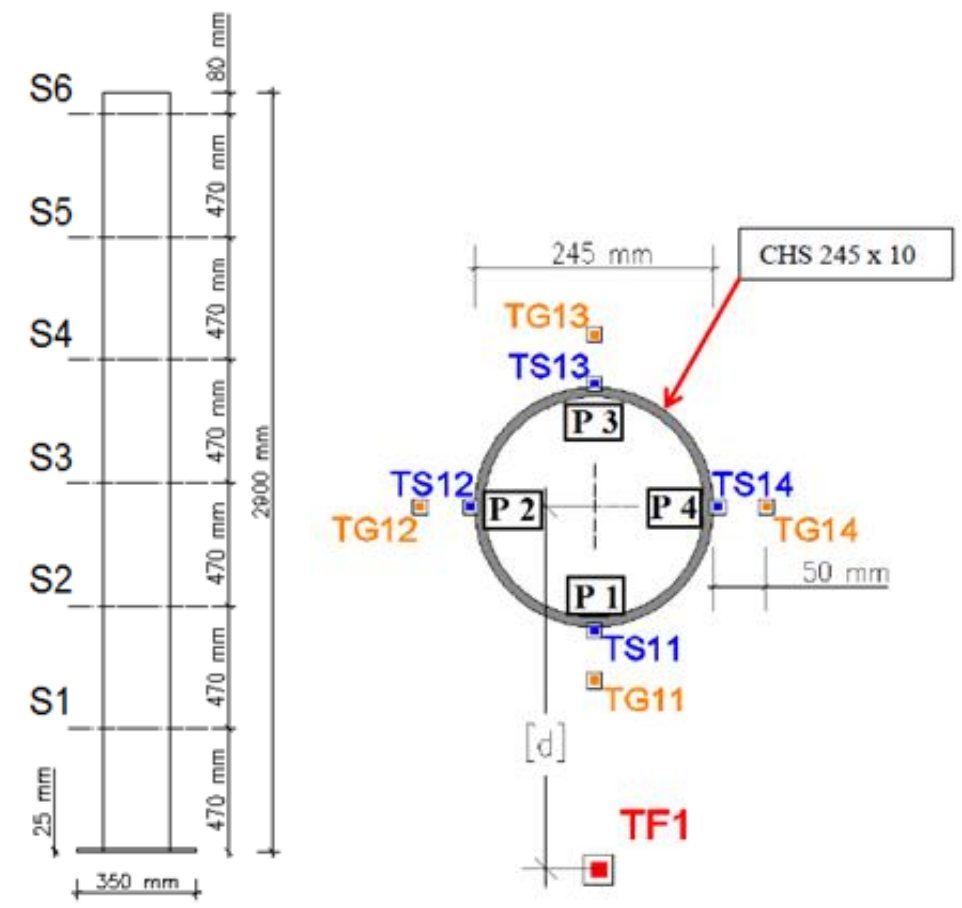

Figure 1 Experimental positioning of the thermocouples

\section{CFD FIRE MODELING}

A previously described experiment was modeled using PyroSim 2017 software, [6]-a graphical user interface for FDS. A few limitations having an impact on this work must be listed: FDS supports only rectilinear geometry, lack of experimental data regarding fuel properties, accidentally occurring wind effects during experiments, and limited computational power.

Because wind influence is an important factor in fire plume behavior, an experimental case with the smallest wind influence (Test no. 7, [3]) was chosen as the most appropriate to calibrate.

\subsection{Geometry}

Figure 2 presents the experimental setup within the fire compartment. Furthermore, Figure 3 presents the computational domain, while Figures 4 and 5 present the approximation of the column and fire pool owing to FDS limitations.

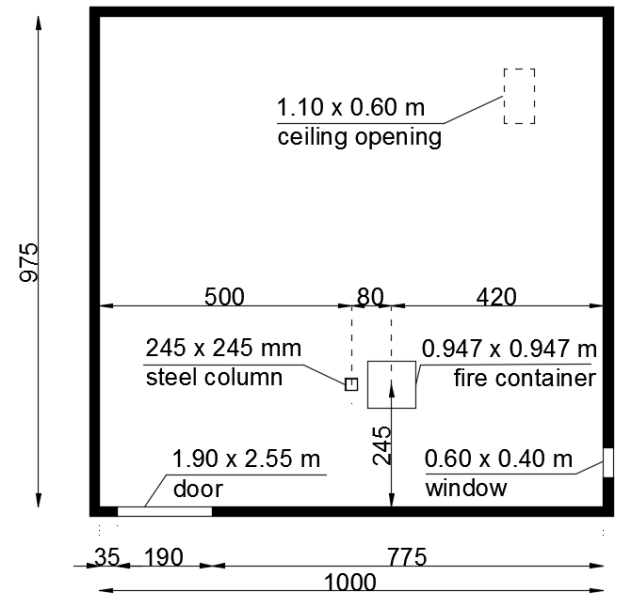

Figure 2 Geometry of fire compartment

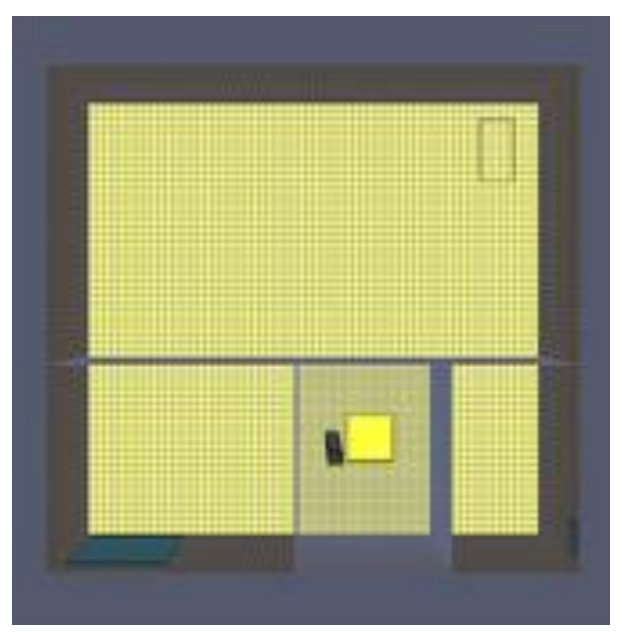

Figure 3 Computational domain

Faldić, T, Craveiro, H, Santiago, A, Torić, N 

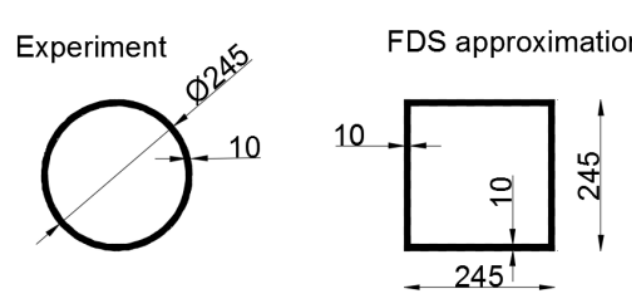

Figure 4 Geometry of steel column
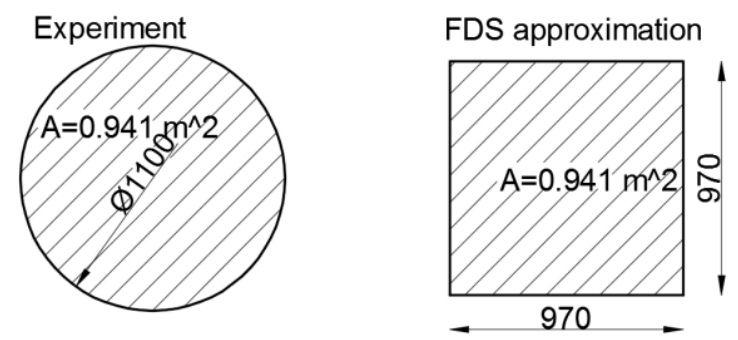

Figure 5 Geometry of fire pool

\subsection{Thermal load}

The pool fire was defined as an S235 steel container with a diameter of $1.10 \mathrm{~m}$. In the experiments, $30 \pm 2$ I of diesel was used. Because diesel is not a well-defined substance, the exact composition of fuel was not known. The only known parameter was the density of diesel, which was measured to be $0.838 \mathrm{~kg} / \mathrm{l}$. The lack of diesel properties was the most significant limitation during the calibration of the fire plume. Some of the most important diesel properties are listed below in Table 1.

Table 1 Fuel properties

\begin{tabular}{lccc}
\hline Properties & Unit & Value & Reference \\
\hline Volume & $(\mathrm{l})$ & 30 & {$[3]$} \\
Density & $\left(\mathrm{kg} / \mathrm{m}^{3}\right)$ & 838 & {$[3]$} \\
Chemical formula & - & $\mathrm{C}_{12} \mathrm{H}_{23}$ & {$[7]$} \\
Specific heat & $(\mathrm{kJ} / \mathrm{kgK})$ & 1.80 & {$[8]$} \\
Vaporization temperature & $\left({ }^{\circ} \mathrm{C}\right)$ & 165 & {$[9]$} \\
Heat of combustion & $(\mathrm{kJ} / \mathrm{kg})$ & $4.50 \mathrm{E}^{4}$ & {$[10]$} \\
Heat of vaporization & $(\mathrm{kJ} / \mathrm{kg})$ & 232 & {$[8]$} \\
Conductivity & - & 0.13 & {$[11]$} \\
\hline
\end{tabular}

\subsection{Steel properties}

The properties of steel used in the experiment to calculate heat transfer within the fire model are based mainly on [5]. Figure 6 presents the properties of steel; steel grade $S 275$ was used. The density of steel- $\rho=7850\left(\mathrm{~kg} / \mathrm{m}^{3}\right)$; emissivity coefficient $\varepsilon=0.75$, [12].
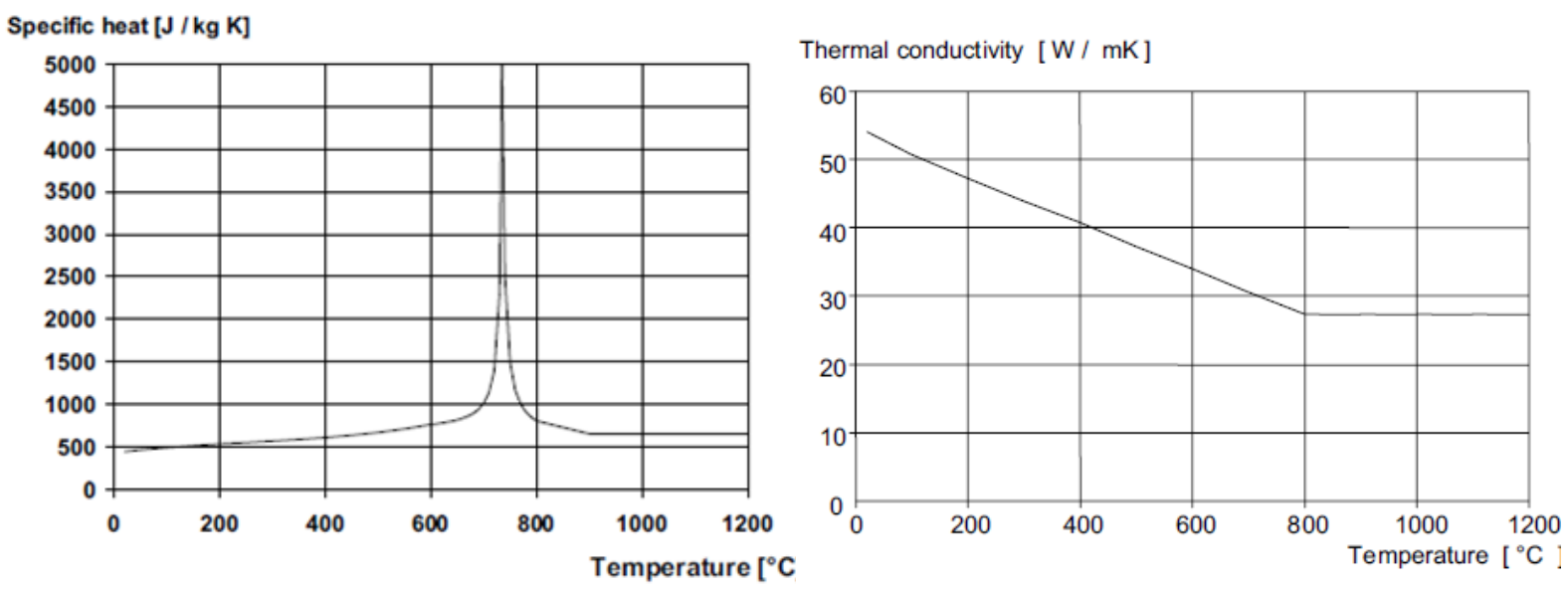

Figure 6 Steel properties 


\subsection{Results and discussion}

In order to test the model sensitivity on grid size, several grid sizes were tested (Table 2). A more detailed presentation of CFD modeling has been presented in [2].

Table 2 Finite element sizes

\begin{tabular}{rrrcc}
\hline Model & Cell size $(\mathbf{c m})$ & $D^{\star} / \delta x$ & $\begin{array}{c}\text { Total number of } \\
\text { cells }\end{array}$ & $\begin{array}{c}\text { Required computational time } \\
\text { (hours) }\end{array}$ \\
\hline FDS_Coarse & $12.0 \times 12.0 \times 12.5$ & 15 & 33360 & $\approx 4.0$ \\
Mesh & & & 216192 & $\approx 50.0$ \\
FDS_Fine Mesh & $6.4 \times 6.4 \times 6.3$ & 30 & 2160 \\
\hline
\end{tabular}

$D^{*} / \delta x$ (Table 2) is the number of computational cells spanning the characteristic diameter of the fire. Furthermore, temperature measuring devices were positioned analogously to the experimental setup. In addition to the temperature, which was measured using thermocouples, the adiabatic surface temperatures were measured as well, in order to perform FEM thermal analysis. Figure 7 presents the positioning of the temperature measuring devices used in the FDS model.

\section{Table 3 Temperature measuring devices positioning}

\begin{tabular}{|c|c|c|c|c|c|}
\hline \multicolumn{2}{|c|}{ Index } & Position & \multicolumn{2}{|c|}{ Index } & \multirow{2}{*}{$\begin{array}{c}\text { Position } \\
\text { (m): }\end{array}$} \\
\hline$i$ & 0 & \multirow{5}{*}{ 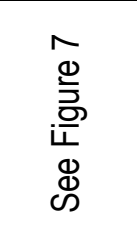 } & $j$ & 1 & \\
\hline & 1 & & & 2 & 0.94 \\
\hline & 2 & & & 3 & 1.41 \\
\hline & 3 & & & 4 & 1.88 \\
\hline & 4 & & & 5 & 2.35 \\
\hline & & & & 6 & 2.88 \\
\hline
\end{tabular}

TCFij - Thermocouple above the fire source

TCCij - Thermocouple on the column surface (steel temperature)

ASTij-Adiabatic surface temperature

$i$ - height of obtained section

$j$ - position on the cross section

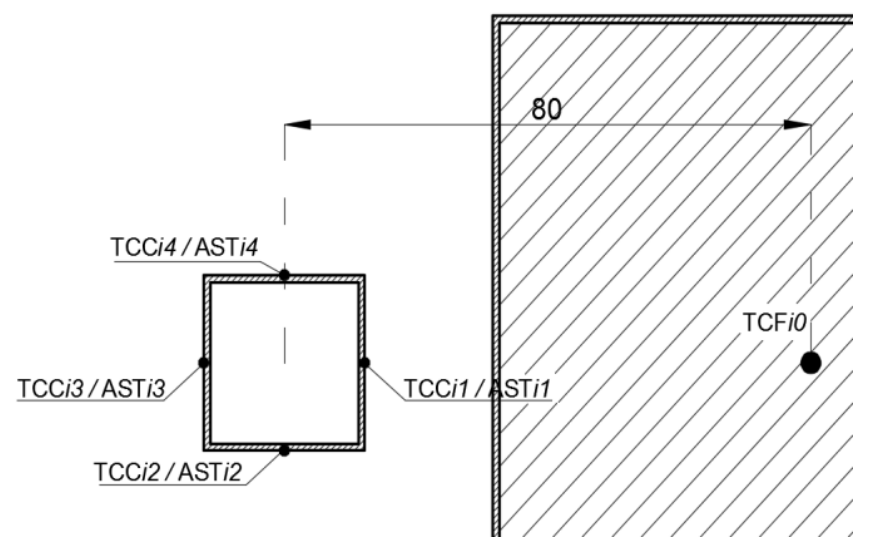

Figure 7 Positioning of temperature measuring devices 

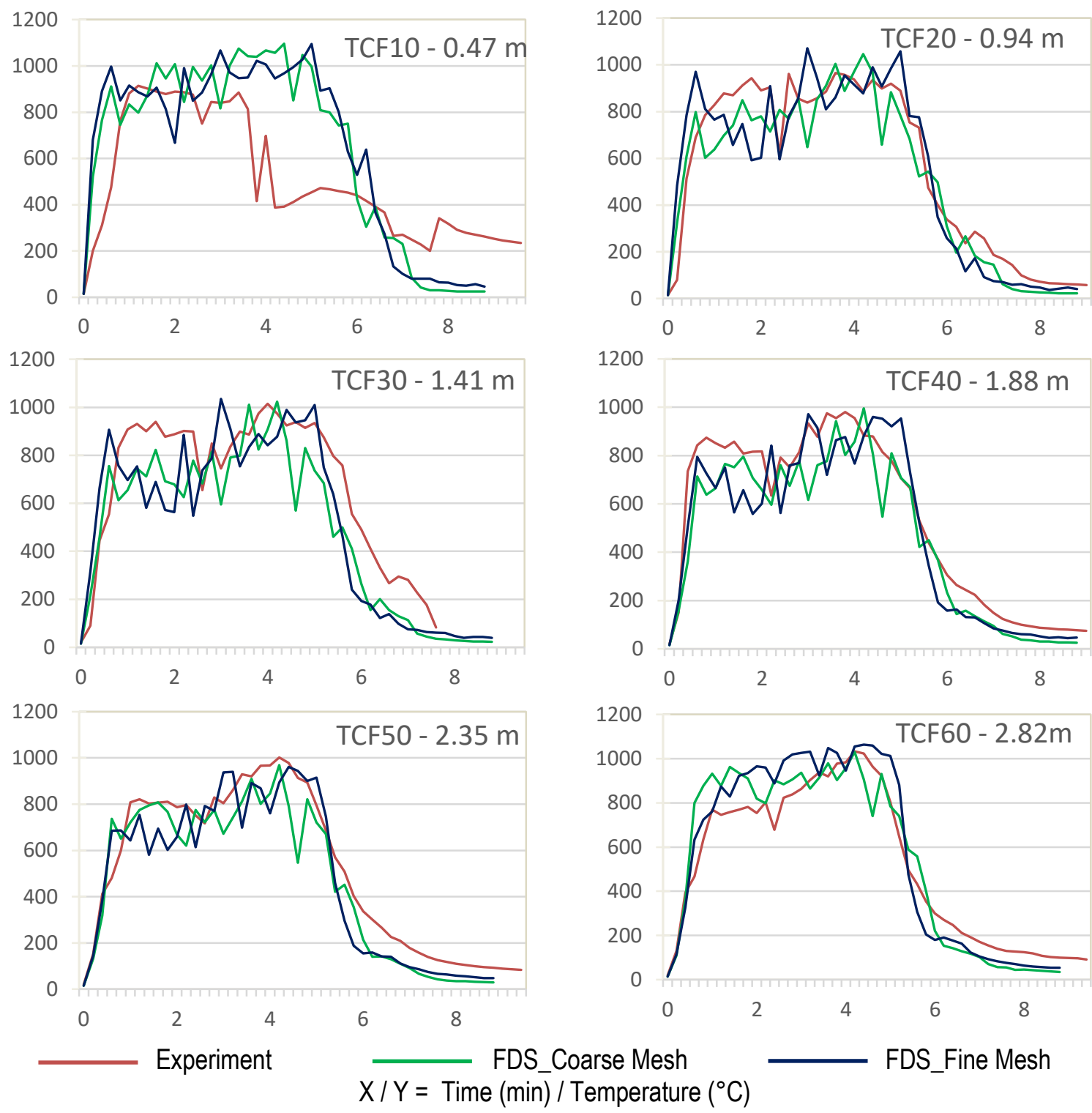

Figure 8 Temperatures in the vertical axis of fire plume

As can be seen in Figure 8, it is obvious that the fire duration and temperatures predicted by FDS are quite good. It should be noted that the sudden drop ( $\approx \approx 4 \mathrm{~min}$ ) observed in the temperature curve, measured by TCF10, was due to thermocouple failure, [3]. Furthermore, it can be observed that the grid size does not significantly affect fire behavior in the vertical axis of the fire plume in terms of duration and temperatures. The reason for peak appearances in the numerical models, as in the experiments, is the deflection of the fire plume caused by accidental winds. The adiabatic surface temperatures obtained from the FDS_Fine Mesh model were used to calculate 3D heat transfer by using the FEM (Finite Element Method) software.

\section{THERMAL ANALYSIS}

The numerical modeling of the heat transfer phenomena was conducted using the FEM software Abaqus/CAE 6.13. Heat transfer was calculated as a transient state over a time period of $25 \mathrm{~min}$. The column was modeled as a solid, and meshed using 5-mm DC3D8 elements, which are 8-node linear heat transfer elements. As mentioned previously, the adiabatic surface temperatures were used to calculate steel temperatures. Following the 
experimental measurements, the outside surface of the column was divided into 24 regions, 6 by the height and 4 by the cross sectional area according to the device positions (Table 3 ). The adiabatic surface temperatures obtained in the fire model were set as boundary conditions.

The convective heat transfer coefficient $\left(a_{c}\right)$ was set as $20 \mathrm{~W} / \mathrm{m}^{2} \mathrm{~K}$ for the heat transfer analysis conducted using adiabatic surface temperatures, and $25 \mathrm{~W} / \mathrm{m}^{2} \mathrm{~K}$ for the ISO834 fire curve, [5]. The emissivity of steel $\left(\varepsilon_{\mathrm{s}}\right)$ was 0.75 , [12]. The conductivity and specific heat were temperature dependent, as shown in Figure 5 . In addition to the heat transfer analysis conducted using the adiabatic surface temperatures obtained from the fire model, a heat transfer analysis using the international standard fire curve ISO 834 prescribed in EN 1991-1-2, [1], was also performed to investigate and compare the influence of steel temperatures on its behavior. In this case, the temperature distribution was assumed to be uniform along the entire column. Figure 9 presents a comparison between temperatures obtained from the experiment and the FEM model. Figure 10 presents the heat transfer analysis for the ISO fire, and Figure 11 presents the temperature distribution along the vertical axis of the plume.
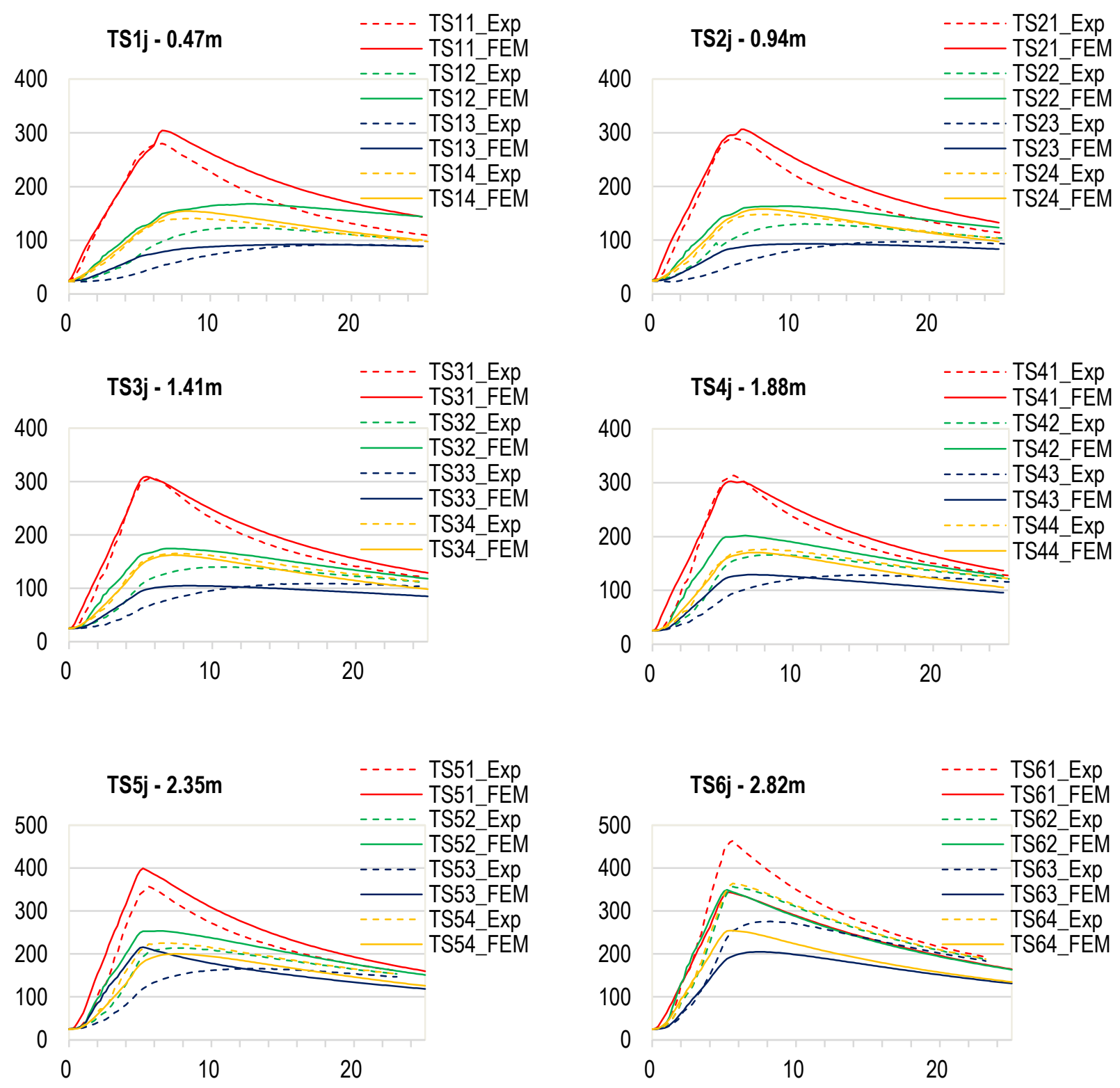

$\mathrm{X} / \mathrm{Y}=$ Time $(\min ) /$ Temperature $\left({ }^{\circ} \mathrm{C}\right)$

Figure 9 Comparison between measured steel temperature 
In the region $T S i 1$, the calculated temperatures showed good agreement with the experimental results, except in the highest region (below the ceiling), where the temperature distribution predicted by the FDS model was underrated. Region TSi2 showed slightly overrated steel temperatures along the entire height of the column, owing to flame deviation in the FDS model. The fire plume behavior was steadier during the experiments that resulted in a smaller difference in steel temperatures along the regions TSi2 and TSi4. The not-exposed side of the column, TSi3, showed well resolved steel temperature calculation in terms of the maximum temperatures, but there are still differences in the time development of the temperature.

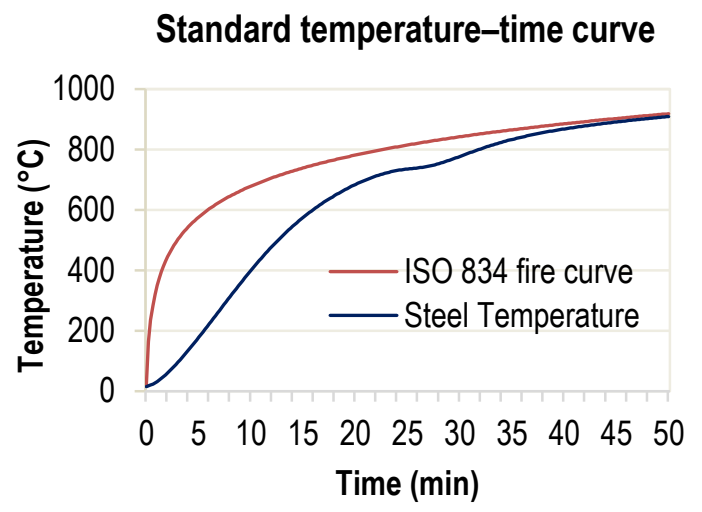

Figure 10 Standard temperature-time curve

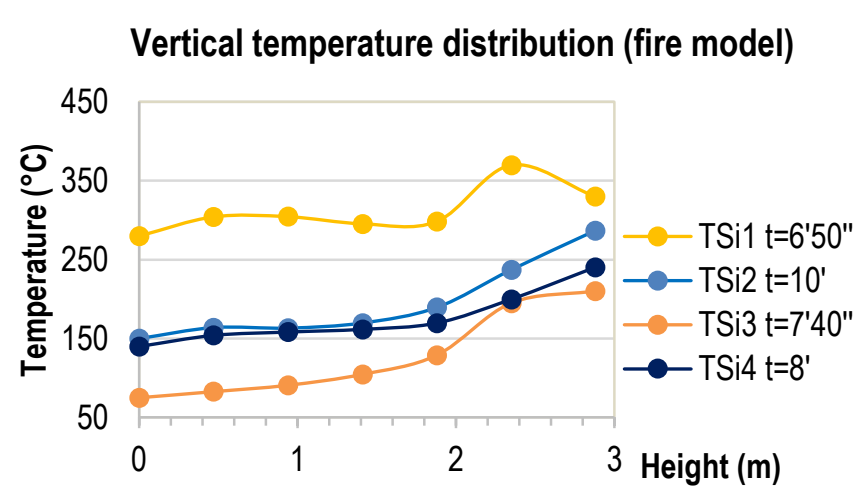

Figure 11 Vertical temperature distribution

\section{STRUCTURAL ANALYSIS}

\subsection{Introduction}

The structural analysis of the column was conducted using the same software, Abaqus/CAE 6.13. The geometry of the column and column divisions in the regions were similar to those mentioned in the previous section. The steel column was modeled as an ideal elastic-plastic material, which neglects strain-hardening under high strains. Because the steel column was subjected to high temperatures, its mechanical properties were assumed to be temperature dependent, [5]. The steel temperatures calculated from the thermal analysis were assigned as predefined fields to the corresponding column regions, as mentioned before. The boundary conditions were assumed as pinned on both the column ends. GMNIA (geometrical and material non-linear analysis with imperfections included) calculation was performed and compared with GMNA (geometrical and material non-linear analysis) calculation. The column was meshed with 10-mm Hex shaped C3D8R elements, which are 8-node linear brick elements. NLGEOM analysis, which includes geometrical nonlinearity, was included in the structural model owing to expected large deflections. Geometrical imperfections are usually introduced by perturbations in the geometry. In this study, geometrical imperfections are observed as initial curvature and eccentricity of loading. Initial curvature was defined to initiate local and/or global buckling in the steel column models. Imperfections caused by an initial curvature were considered using a linear superposition of buckling eigenmodes that approximately represents the imperfection of the column. Furthermore, an eigenvalue buckling analysis at the ambient temperature (Figure 13) was conducted in Abaqus/CAE prior to static analysis. The superposition of selected eigenmodes was performed with the appropriate scale factor while performing the static analysis. First, two buckling modes were used in the presented analysis, as shown in the following figure. Thus, the following two scale factors were selected: 0.1 times the section thickness for the first buckling mode and 0.05 times the section thickness for the second buckling mode. The eccentricity of loading was taken as $1 / 5$ of the column diameter, which corresponds to $50 \mathrm{~mm}$, and it was applied as concentrated moment on both the column ends. The value of the axial compression force was determined relative to the flexural buckling resistance of the column. 


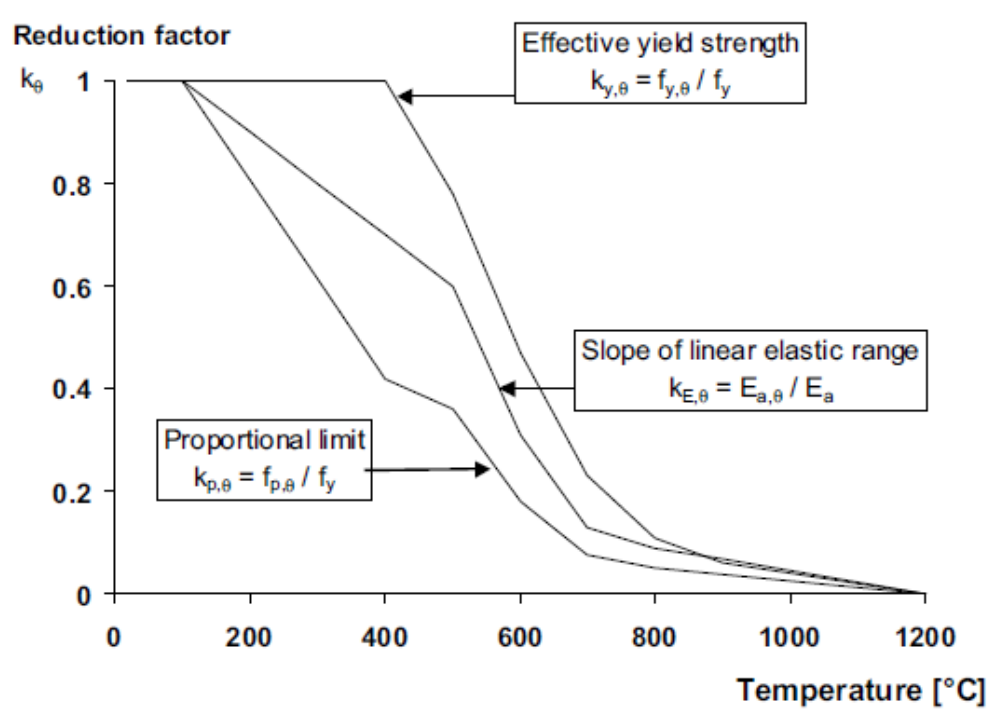

Steel S275

Figure 12 Reduction factors of material properties [5]
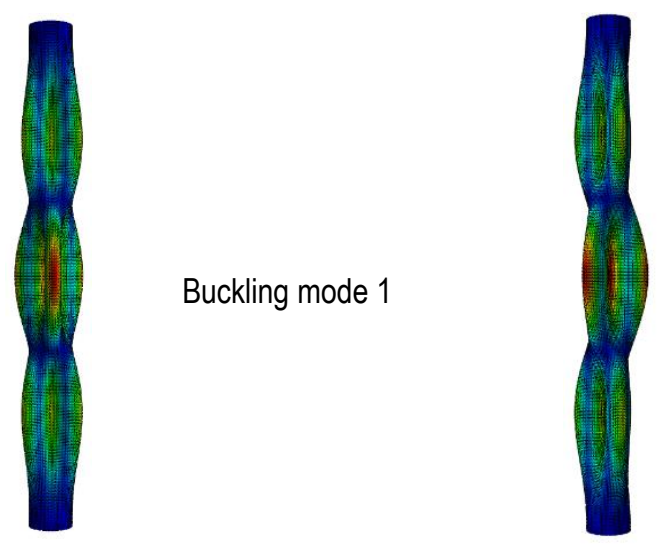

Buckling mode 2

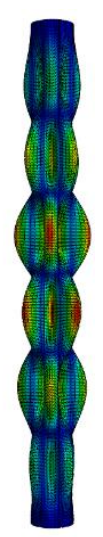

Buckling mode 2

Figure 13 Buckling modes

Figure 12 presents the decrease in material properties by using the reduction factors proposed by [5]. Structural analysis was conducted according to Table 4.

Table 4 Structural analysis concept

\begin{tabular}{|c|c|c|c|c|}
\hline \multirow[b]{3}{*}{ Group } & \multicolumn{4}{|c|}{ Thermal load } \\
\hline & \multicolumn{2}{|c|}{ Fire Model } & \multicolumn{2}{|c|}{ Standard temperature-time curve ${ }^{*}$} \\
\hline & Analysis & Load eccentricity (mm) & Analysis & Load eccentricity (mm) \\
\hline \#1 & GMNA (a) & 1 & GMNA (d) & 1 \\
\hline $\mathrm{N}=0.8 \mathrm{~N}_{\mathrm{b}, \mathrm{Rd}}$ & GMNIA (b) & 0 & GMNIA (e) & 0 \\
\hline $\mathrm{N}=1452 \mathrm{kN}$ & GMNIA (c) & 50 & GMNIA (f) & 50 \\
\hline \#2 & GMNA (a) & I & GMNA (d) & I \\
\hline $\mathrm{N}=0.6 \mathrm{~N}_{\mathrm{b}, \mathrm{Rd}}$ & GMNIA (b) & 0 & GMNIA (e) & 0 \\
\hline $\mathrm{N}=1089 \mathrm{kN}$ & GMNIA (c) & 50 & GMNIA (f) & 50 \\
\hline \#3 & GMNA (a) & I & GMNA (d) & I \\
\hline $\mathrm{N}=0.4 \mathrm{~N}_{\mathrm{b}, \mathrm{Rd}}$ & GMNIA (b) & 0 & GMNIA (e) & 0 \\
\hline $\mathrm{N}=726 \mathrm{kN}$ & GMNIA (c) & 50 & GMNIA $(f)$ & 50 \\
\hline
\end{tabular}

*Thermal load obtained using standard temperature-time curve was assigned as uniform along whole column.

Faldić, T, Craveiro, H, Santiago, A, Torić, N 


\subsection{Results}

The following graphs show the lateral displacement-time dependence for the observed column.

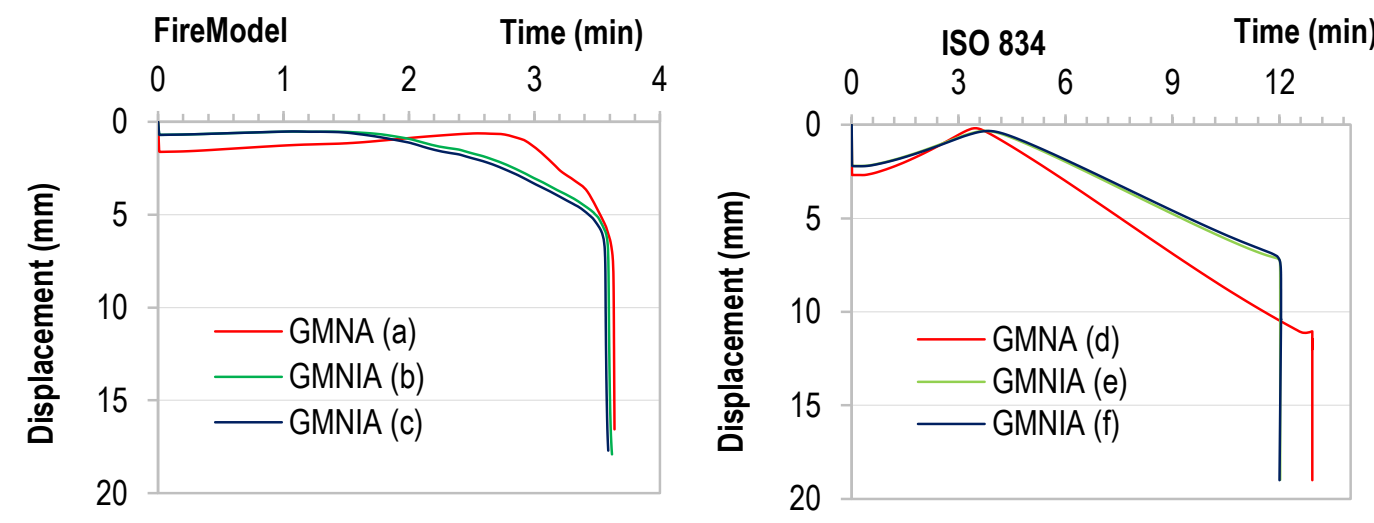

Figure 14 Group \#1

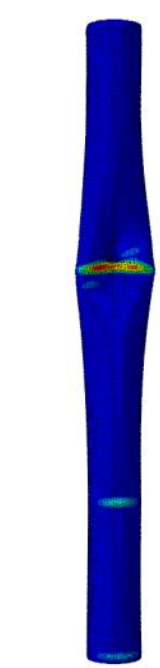

GMNA (a)
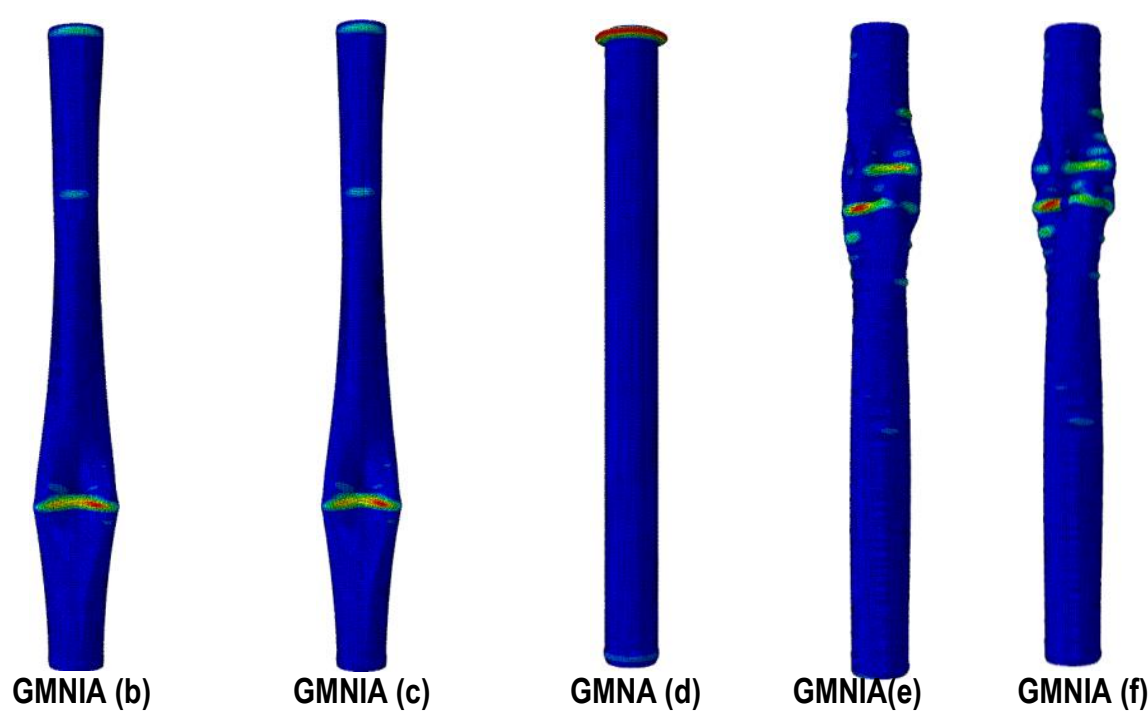

Figure 15 Plastic strain distribution (deformation scale factor=10)
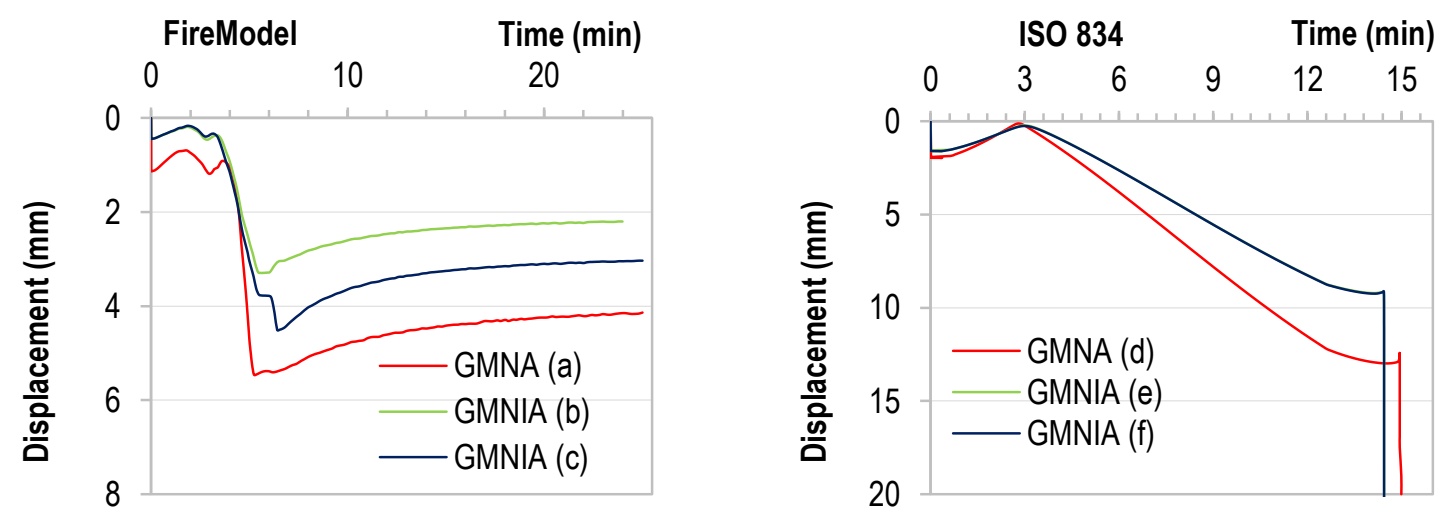

Figure 16 Group \#2 


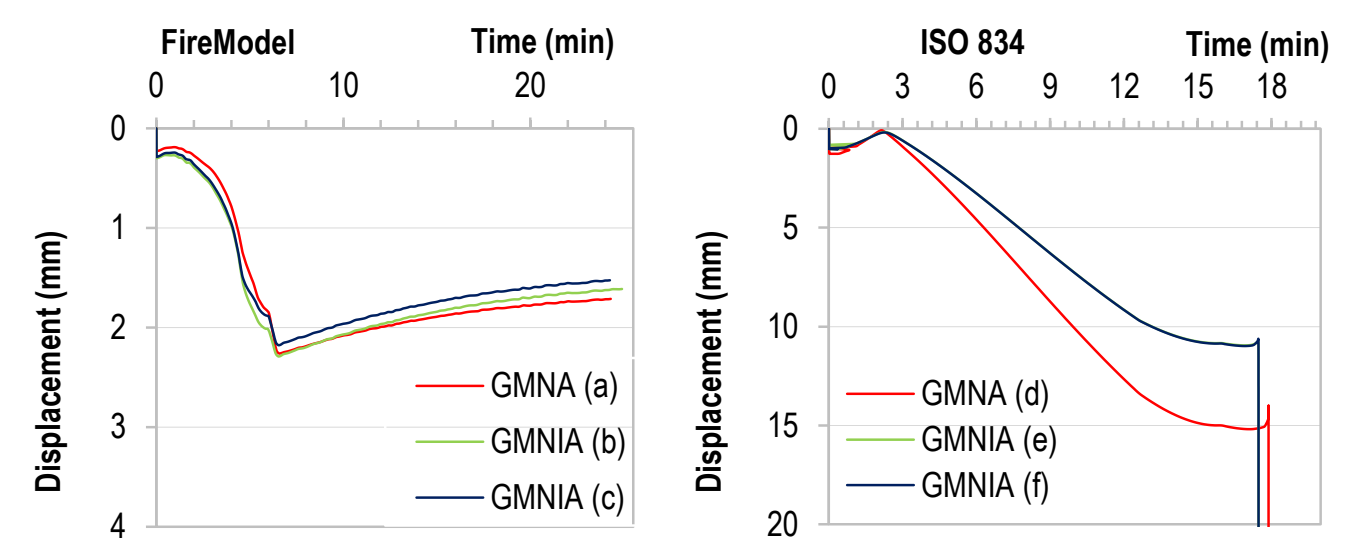

Figure 17 Group \#3

\section{DISCUSSION OF THE RESULTS}

Looking at the results within Group \#1 (Figure 14), where a column is subjected to the maximum axial load, the effect of uniform and non-uniform thermal loads on the column load capacity is clearly observed. Although there is no decrease in yield strength at temperatures where a non-uniformly heated column undergoes failure, there is a decrease in elastic modulus, which results in a higher strain level. Because thermal load is asymmetric, the strain distribution is asymmetric as well (Figure 15). Consequently, this distribution leads to column deflection and causes the applied compression force to become eccentric, which ultimately causes additional internal moments in the column. With the increase in deflections, internal moments increase as well, which ultimately influences earlier column collapse. This phenomenon is a consequence of the second-order effect affecting the column response.

Furthermore, test Group \#2 (Figure 16), as well as Group \#3 (Figure 17), showed that in cases when a lower level of load is expected, the approach using the standard time-temperature fire curve might be too conservative. In this case, a non-uniform thermal load predicts no failure for cases with or without geometrical imperfections, but still permanent deformations on the column exist. In cases where the standard temperature-time fire curve is used, failure occurred at approximately the same temperature for all types of analysis. The time at which the uniformly loaded column collapsed indicates that failure occurred due to degradation of material properties under high temperatures. The initial compressive force eccentricity showed negligible influence owing to the low slenderness of the column.

\section{CONCLUSIONS}

Throughout this work, the performance-based approach is carried out on a steel column exposed to a localized fire, in terms of fire modeling and thermal and structural analyses. EN1991-1-2 provides a simple calculation approach for determining localized fires within compartments; however, there is no simplified method to calculate heat transfer to vertical elements. Therefore, there is a need to investigate the effect of a localized fire to vertical structural elements, such as columns. As a result of these analyses, it has been shown how a non-uniform thermal load caused by a localized fire may induce collapse of the structure, although the maximum temperatures reached are significantly lower than those calculated using the standard temperature-time curve at the moment when failure occurs, for the same level of axial load. For a high axial load, the column exposed to a localized fire undergoes failure much earlier than the same column exposed to uniform heating. A non-uniform thermal load caused asymmetric deflections and eventually induced column collapse owing to second-order effects.

Therefore, it has been shown that a localized fire can result in unwanted consequences. For the observed fire scenarios, a column exposed to a localized fire undergoes collapse about three times faster than the same column under a uniform thermal load calculated using the standard temperature-time curve. An earlier column collapse implies less time for evacuation of occupants. 
Finally, although this analysis is complex and time consuming, the benefits of it could be quantified in terms of increasing safety and reliability. Recent studies [13] have shown that it is important to consider the effect of localized fires not only in small fire compartments but also in large fire compartments such as airport terminals, odeums, stadiums, and other structures intended for public use. Consequently, further research on localized fires should be conducted to develop simplified methods to calculate heat transfer to vertical structural elements.

\section{References}

[1] EN 1991-1-2, 2002: Actions on structures - Part 1-2: General actions - Actions on structures exposed to fire, European Committee for Standardization, Brussels

[2] Faldić, T. 2017: Structural analysis of the steel column exposed to a localised fire, Master thesis, University of Split, Faculty of civil engineering, architecture and geodesy

[3] Ferraz G. 2014: Thermal analysis of steel columns exposed to localised fires, Master thesis, University of Coimbra

[4] Wickström U. 2016: Temperature Calculation in Fire Safety Engineering, Springer, Switzerland

[5] EN 1993-1-2, 2005: Design of steel structures - Part 1-2: General Rules - Structural fire design, European Committee for Standardization, Brussels

[6] Pyrosim User Manual, 2015: Thunderhead engineering

[7] https://en.wikipedia.org/wiki/Diesel fuel\#Chemical_analysis, Accessed May 2017

[8] http://walshcarlines.com/pdf/fueltable.pdf, Accessed May 2017

[9] Britannica: Vaporization, https://www.britannica.com/science/vaporization, Accessed May 2017

[10] Nist Chemistry WebBook (http://webbook.nist.gov/), USA, Accessed May 2017

[11] http://www.engineeringtoolbox.com/thermal-conductivity-liquids-d 1260.html, Accessed May 2017

[12] https://www.omega.com/literature/transactions/volume1/emissivitya.html, Accessed May 2017

[13] Peko, J.; Torić, N.; Boko, I. 2016: Comparative analysis of steel and aluminum structures, Electronic Journal of the Faculty of Civil Engineering Osijek-e-GFOS, 13, pp. 50-61, https://doi.org/10.13167/2016.13.6

Please cite this article as:

Faldić, T.; Craveiro, H.; Santiago, A.; Torić, N.: Structural analysis of a steel column exposed to a localized fire, Electronic Journal of the Faculty of Civil Engineering Osijek-e-GFOS, 15, pp. 1-12, https://doi.org/10.13167/2017.15.1 